\title{
Resilient Remediation: Addressing Extreme Weather and Climate Change, Creating Community Value
}

\begin{abstract}
Recent devastating hurricanes demonstrated that extreme weather and climate change can jeopardize contaminated land remediation and harm public health and the environment. Since early 2016, the Sustainable Remediation Forum (SURF) has led research and organized knowledge exchanges to examine (1) the impacts of climate change and extreme weather events on hazardous waste sites, and (2) how we can mitigate these impacts and create value for communities.
\end{abstract}

The SURF team found that climate change and extreme weather events can undermine the effectiveness of the approved site remediation, and can also affect contaminant toxicity, exposure, organism sensitivity, fate and transport, long-term operations, management, and stewardship of remediation sites. Further, failure to consider social vulnerability to climate change could compromise remediation and adaptation strategies.

SURF's recommendations for resilient remediation build on resources and drivers from state, national, and international sources, and marry the practices of sustainable remediation and climate change adaptation. They outline both general principles and site-specific protocols and provide global examples of mitigation and adaptation strategies. Opportunities for synergy include vulnerability assessments that benefit and build on established hazardous waste management law, policy, and practices. SURF's recommendations can guide owners and project managers in developing a site resiliency strategy. Resilient remediation can also help expedite cleanup and redevelopment, decrease public health risks, and create jobs, parks, wetlands, and resilient energy sources. Resilient remediation and redevelopment can also help achieve 
international goals for sustainable land management, climate action, clean energy and sustainable cities.

\section{Introduction}

After Hurricane Harvey made landfall in 2017, 13 Superfund sites in Houston, Texas were flooded. At one site, the EPA measured dioxin at levels over 2,300 times the level requiring cleanup actions. Five weeks after Hurricane Maria hit in 2017, one in four Puerto Ricans lacked access to clean water. During Hurricane Florence, EPA and scientists from industry, universities, and civil organizations warned of the potential release of toxic chemicals from North Carolina and South Carolina Superfund sites. Post landfall, Florence led to extensive flooding that “...swept away part of a retaining wall holding back a pond of coal ash - which contains mercury, arsenic and other toxic substances - and have also overrun several lagoons of pig waste in North Carolina." (Pierre-Louis et al., 2018 p1).

In the U.S., nearly two million people - the majority in low income communities-live within one mile of one of 327 Superfund sites in areas prone to flooding or vulnerable to sealevel rise caused by climate change (Dearen et al., 2017). These 327 sites are part of a much larger universe of U.S. sites that need to be assessed. There are more than 650,000 contaminated commercial and industrial sites and more than 81,000 acres of brownfields at 21,000 sites in 232 cities across the U.S. (Targ, 2017).

Globally, the number of contaminated sites is overwhelming and growing as a result of increasing urbanization especially in emerging economies. Estimates for Europe alone (excluding many diffuse land contamination problems) range from 2.5 to 4.5 million sites. In 
China, about 20 percent of farmland is contaminated by trace metals, pesticides, and hydrocarbons such as petrochemicals (Bardos et al., 2011). Over one million contaminated sites may require cleanup (Hou and $\mathrm{Li}, 2017$ ), and nearly $60 \%$ of groundwater is not safe for drinking (Hou et al., 2018). And public health threats can exist even on contaminated land which has been remediated.

\section{Research Findings}

Decades of research, including the recent 2017 U.S. Climate Science Special Report, (Wuebbles et al., 2017) document the global reality of more powerful and frequent storms, heavy rainfall, heat waves, wildfires, and more frequent and longer droughts. Rising sea levels, declining snowpack, long-term stress on water availability, dynamic groundwater levels, acidification, and rising temperatures represent further threats to ecosystems and communities.

At hazardous sites, climate change and extreme weather events can undermine the effectiveness of the original site remediation design and can also impact contaminant toxicity, exposure, organism sensitivity, fate and transport, and long-term operations, management, and stewardship of remediation sites.

Higher temperature and lower $\mathrm{pH}$, can increase the availability of contaminants in the environment. For example, the speciation and availability of metals changes with environmental pH (Millero et al., 2009), and the fate and transport of persistent organic pollutants changes with temperature and precipitation (Nadal et al., 2015).

Increasing temperatures can also change the water cycle influencing the local water budget. Warmer temperatures can result in altered precipitation, increased evaporation rates of 
surface water, increased rates of water uptake by vegetation, and reduced rates of water recharge to soils and groundwater reservoirs. (Famiglietti et al., 2014).

Increased temperatures and changes to the water cycle may also result in more frequent and severe weather events, such as the occurrence of he 100-year storm event, as well as,contribute to more frequent nuisance flooding due to the prevalence of supersaturated soils. Both events are exacerbated by sea level rise resulting in shoreline encroachment and increased nuisance flooding during high tide.

Additional vulnerabilities of water resources include, but are not limited to, changes to water supplies, subsidence, increased amounts of water pollution, erosion, and related risks to water and wastewater infrastructure and operations, degradation of watersheds, and alteration of aquatic ecosystems and loss of habitat, creating multiple impacts in coastal areas (LARWQCB, 2015). These hydrological changes are happening at the same time as groundwater extraction is increasing as heat also increases demand for various water needs, including drinking, irrigation, and industrial uses (Famiglietti et al., 2014).

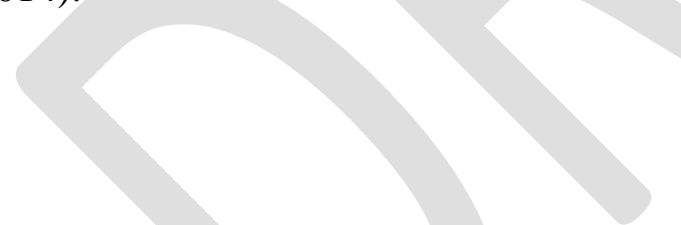

A recent study showed a potential impact of such climatic shifts on residual contaminants in soil and groundwater (Libera et al., 2018). The study found that the hydrological shifts influence contaminant concentrations in a complex manner, since increased infiltration, for example, could cause conflicting effects of both diluting and mobilizing contaminants. The study showed that, in general, higher-infiltration events could mobilize vadose-zone residual contaminants, raising contaminant concentrations in groundwater for a prolonged period. 
Similarly, the sensitivity of organisms and ecosystems can be affected by environmental change. Higher temperatures increase the metabolic rate of ectotherms (organisms which derive their heat and, therefore, maintain their metabolic activity from the environment around them), which can increase the rate at which they absorb or process contaminants (Noyes et al., 2009). Behavioral changes in response to environmental change may also alter exposure and sensitivity as organisms react to new stresses in ways that ameliorate or exacerbate other stresses.

The use of the chemicals that become environmental contaminants is also likely to change. For example, warming temperatures leads to expansion of agricultural pests, resulting in increased use of pesticides. Furthermore, more rain may require repeated application of pesticides and fertilizers. Both scenarios can result in agricultural land contaminated by intense application of chemicals as well as contributions to polluted runoff that impact nearby and downgradient waterbodies.

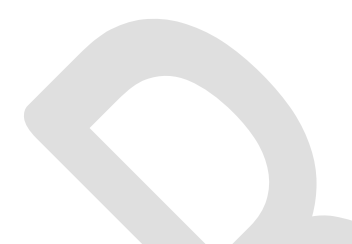

Climate change also poses challenges for selecting remediation techniques, including the feasibility of passive remediation technologies (O'Connell and Hou, 2015). Passive remediation carries an increased burden of proof, since contaminants stay longer in the subsurface compared to conventional soil removal options - while degradation/treatment processes occur.

Thus, the efficacy of remediation efforts may be undermined if attention is not paid to climate change impacts throughout the remediation process. This can be thought of from two different perspectives: 1) how climatic change will affect remediation, and 2) how remediation techniques will be affected by climate change. Examples of each are presented in Exhibits 1 and 2. 
Exhibit 1 Implications of climate change for remediation

\begin{tabular}{|c|c|c|}
\hline Climate Impact & Secondary Effect & Relevant Remediation Effect \\
\hline \multirow[t]{10}{*}{$\begin{array}{l}\text { Altered Precipitation } \\
\text { Pattern }\end{array}$} & \multirow[t]{3}{*}{$\begin{array}{l}\text { Wetter: Flooding, } \\
\text { storms, more run-off }\end{array}$} & $\begin{array}{l}\text { Mobilization of contaminants (e.g., from } \\
\text { vadose zone to groundwater) } \rightarrow \text { higher } \\
\text { contaminant concentration/export, } \\
\text { overpowering significant degradation rate in } \\
\text { groundwater zone could remove natural } \\
\text { protective barriers or cause infill subsidence in } \\
\text { low-lying areas }\end{array}$ \\
\hline & & $\begin{array}{l}\text { Dilution } \rightarrow \text { lower contaminant } \\
\text { concentration/export }\end{array}$ \\
\hline & & Damage to capping systems \\
\hline & \multirow[t]{6}{*}{ Drier: Drought } & Oxidation of soils \\
\hline & & Increased volatility \\
\hline & & $\begin{array}{l}\text { Less dilution } \rightarrow \text { higher contaminant } \\
\text { concentration/export }\end{array}$ \\
\hline & & $\begin{array}{l}\text { Reduced mobilization } \rightarrow \text { higher contaminant } \\
\text { persistence (higher contaminant } \\
\text { concentration/export) }\end{array}$ \\
\hline & & $\begin{array}{l}\text { Insufficient water for remediation; } \\
\text { Overuse of groundwater }\end{array}$ \\
\hline & & $\begin{array}{l}\text { Possible enhanced natural attenuation, } \\
\text { expedited contaminant removal }\end{array}$ \\
\hline & Altered Salinity & Altered degradation rates (physical, microbial) \\
\hline \multirow[t]{4}{*}{ Sea Level Rise } & Erosion & Damage to site integrity \\
\hline & Site Inundation & $\begin{array}{l}\text { Increased mobilization of contaminants, } \\
\text { possible dilution, or compromised site with } \\
\text { mixing or loss of contaminated materials, } \\
\text { increased bioavailability of contaminants }\end{array}$ \\
\hline & $\begin{array}{l}\text { Mobilization of } \\
\text { contaminants }\end{array}$ & $\begin{array}{l}\text { Clean sediments transported on top of } \\
\text { contaminated sediments }\end{array}$ \\
\hline & Elevations increase & $\begin{array}{l}\text { Changing footprint of flood plains, river } \\
\text { boundaries, and coastal shoreline } \\
\text { encroachment } \rightarrow \text { impact on regulations (e.g., } \\
\text { dredging, cleanup levels, negotiation of water } \\
\text { levels, monitoring) }\end{array}$ \\
\hline Extreme Weather & $\begin{array}{l}\text { Scour (wind/wave } \\
\text { action; surface water } \\
\text { flow velocity) }\end{array}$ & Damage to site integrity, capping systems \\
\hline
\end{tabular}




\begin{tabular}{|c|c|c|}
\hline & Flooding & $\begin{array}{l}\text { Possible dilution (lower contaminant } \\
\text { concentration/export), or compromised site } \\
\text { with mixing or loss of contaminated materials, } \\
\text { damage to capping systems }\end{array}$ \\
\hline & \multirow[t]{3}{*}{ Extreme Heat } & $\begin{array}{l}\text { Increased volatility } \rightarrow \text { Mobilization of } \\
\text { contaminants from site through soil and air }\end{array}$ \\
\hline & & Changes in use of site by wildlife \\
\hline & & $\begin{array}{l}\text { Melting permafrost } \rightarrow \text { Mobilization of } \\
\text { contaminants from site through water, soil and } \\
\text { air }\end{array}$ \\
\hline & Freezing conditions & $\begin{array}{l}\text { Damage to capping systems and in situ } \\
\text { stabilization systems }\end{array}$ \\
\hline \multirow[t]{2}{*}{ Extreme Weather: Fire } & $\begin{array}{l}\text { Increased use of fire } \\
\text { retardants }\end{array}$ & Spread of contaminants \\
\hline & $\begin{array}{l}\text { Damage to site } \\
\text { infrastructure }\end{array}$ & Loss of function of remediation systems \\
\hline \multirow[t]{3}{*}{ Decreasing $\mathrm{pH}$} & & Increased availability, mobilization, toxicity \\
\hline & & $\begin{array}{l}\text { Increased sensitivity of species due to } \mathrm{pH} \\
\text { stress }\end{array}$ \\
\hline & & Altered transformation rates \\
\hline \multirow[t]{3}{*}{ Increasing Temperature } & $\begin{array}{l}\text { Altered } \\
\text { transformation or } \\
\text { degradation }\end{array}$ & Increased or decreased toxicity \\
\hline & $\begin{array}{l}\text { Decreased dissolved } \\
\text { oxygen/anoxic } \\
\text { conditions }\end{array}$ & $\begin{array}{l}\text { Altered transformation, decreased species } \\
\text { resilience }\end{array}$ \\
\hline & $\begin{array}{l}\text { Increased species } \\
\text { heat stress and } \\
\text { associated } \\
\text { conditions }\end{array}$ & Increased sensitivity to contaminants \\
\hline \multirow[t]{2}{*}{$\begin{array}{l}\text { Human Impact \& } \\
\text { responses }\end{array}$} & $\begin{array}{l}\text { Vulnerable } \\
\text { communities } \\
\text { commonly } \\
\text { comprised of low } \\
\text { socio-economic and } \\
\text { minority populations }\end{array}$ & $\begin{array}{l}\text { Cardio-pulmonary illness } \\
\text { Food, water and vector borne diseases } \\
\text { Loss of homes, drinking water and livelihoods } \\
\text { mental health consequences and stress }\end{array}$ \\
\hline & $\begin{array}{l}\text { Increased use of } \\
\text { some chemicals } \\
\text { Conflicting } \\
\text { solutions, changing } \\
\text { land use demands, } \\
\text { shifting populations }\end{array}$ & $\begin{array}{l}\text { Additional toxicity, additional remediation } \\
\text { sites. }\end{array}$ \\
\hline
\end{tabular}


Exhibit 2 Impact of climate change on remediation techniques*

\begin{tabular}{|l|l|l|}
\hline $\begin{array}{l}\text { Remediation } \\
\text { Approach }\end{array}$ & Technique & Climate Change Impact \\
\hline Soil Treatment & Bioremediation & $\begin{array}{l}\text { Degradation activity may change, unexpected } \\
\text { intermediaries }\end{array}$ \\
\cline { 2 - 3 } & Landfarming/landspreading & Inundation of site by sea level rise or flooding \\
\hline $\begin{array}{l}\text { Groundwater } \\
\text { Treatment }\end{array}$ & Pump and treat & Altered rate of recharge and extraction \\
\hline $\begin{array}{l}\text { Removal of } \\
\text { Contaminated } \\
\text { Materials }\end{array}$ & & $\begin{array}{l}\text { Extreme weather, flooding, or sea level rise } \\
\text { will complicate containment } \\
\text { Groundwater level decline may support } \\
\text { expedited removal }\end{array}$ \\
\hline $\begin{array}{l}\text { Engineered In } \\
\text { Situ Solutions }\end{array}$ & Soil washing & Insufficient water would limit feasibility \\
\cline { 2 - 3 } & Soil extraction & Warmer temperatures may help \\
\cline { 2 - 3 } & Natural attenuation & $\begin{array}{l}\text { Models do not include climate change which } \\
\text { may alter resident time of contaminants in soil } \\
\text { a attenuation rates may vary }\end{array}$ \\
\cline { 2 - 3 } & Incineration & $\begin{array}{l}\text { Emissions allowances may change due to } \\
\text { temperature or greenhouse gases }\end{array}$ \\
\cline { 2 - 3 } & Capping systems & $\begin{array}{l}\text { Climate change may degrade the cap (e.g., } \\
\text { because of extreme precipitation events) } \\
\text { much higher contaminant concentration/export } \\
\text { and increased mobilization of contaminants in } \\
\text { vadose zone }\end{array}$ \\
\hline & &
\end{tabular}

*See also US EPA fact sheets developed for Contaminated Sediments, Groundwater Remediation Systems and Landfills and other Containment remediation 


\section{Societal Impacts, Legal Implications}

The National Climate Assessment (NCA) provides an in-depth assessment of climate change impacts on the lives of Americans; , the Fourth NCA noted: that "extreme weather events have cost the United States $\$ 1.1$ trillion since 1980.” (Hibbard et al 2017). And The U.S. Government Accounting office warned that climate change "could increase flooding costs in coastal communities by $\$ 23$ billion per year by midcentury" (Plumer, 2017).

Communities adjacent to contaminated sites are often comprised of socio-economically depressed and environmental justice (sensitive) populations that usually have little influence over the decision-making process, even when they are most impacted. North Carolina residents evacuated during Hurricane Florence shared the fate of New Orleans residents post Katrina ... "the poor are always vulnerable- to the perceived values of their residences in good times and the ravages of Mother Nature when disaster hits." (Fausset, 2018 p1).

Parties liable under the U.S. Comprehensive Environmental Response, Compensation and Liability Act (CERCLA) can face additional liability if global warming-related weather events exacerbate problems on contaminated properties. There is no minimum quantity of a hazardous substance needed to establish liability, and a generator or transporter is liable whether or not the hazardous substances they generated or transported are the primary contaminants of concern at the site. All of the parties (current and past owners and operators, generators, and transporters) are also liable if contaminants migrate from the original disposal area.

CERCLA contains an "Act of God" defense, defining an "Act of God" as "an unanticipated grave natural disaster or other natural phenomena of an exceptional, inevitable, and irresistible character, the effects of which could not have been prevented or avoided by the exercise of due care or foresight” (42 USC § 9601(1)(1980)). 
CERCLA also specified three steps necessary to succeed with the Act of God defense. First, the defendant will have to prove that the Act of God was the "sole cause" of the hazardous substances release (42 U.S.C. $§ 9607(b)(1)(1980)$ ). Second, the defendant will have to prove the event was "unanticipated" (42 U.S.C. § 9601(1)(1980)). Third, the defendant will have to prove that the effects of the event "could not have been prevented or avoided by the exercise of due care or foresight" Id. The failure to date of the Act of God defense is illustrated by the results in the cases in which it has been unsuccessfully attempted (see, e.g., U.S. v. Stringfellow, 661 F.Supp. 1053 (C.D. CA 1987); U.S. v. W.R. Grace \& Co.-Conn., 280 F.Supp.2d 1135 (D. MT 2002); U.S. v. Alcan Aluminum Corp., 892 F. Supp. 648 (M.D. Pa. 1995), aff'd, 96 F.3d 1434 (3d Cir. 1996); U.S. v. Barrier Industries, Inc., 991 F. Supp. 678 (S.D. N.Y. 1998); U.S. v. M/V Santa Clara I, 887 F. Supp. 825, 843 (D.S.C. 1995)).

As part of a U.S. government-wide effort, the U.S. Environmental Protection Agency (EPA) began analyzing how climate change could impact the nation's most hazardous sites and developing best practices for the most vulnerable remediation techniques (https://www.epa.gov/superfund/superfund-climate-change-adaptation). EPA also reported on additional community benefits of climate change adaptation at "Brownfields" and recommended land use, zoning, and building code changes and/or development incentives that could increase resiliency (https://www.epa.gov/brownfields/climate-adaptation-and-brownfields).

\section{Overarching Resilient Remediation Principles}

SURF recommendations to advance climate change resilience within contaminated lands rehabilitation build on these EPA initiatives, along with well established climate change adaptation tenets, marrying them with sustainable remediation principles and practices. SURF's 
Sustainable Remediation Framework calls for "a systematic, process-based, iterative, holistic approach beginning with the site end use in mind(Holland et al 2011). This holistic approach can incorporate planning for uncertainty, reducing the rate and extent of local, regional, and global climate change impacts, and address social impacts, equity concerns, and opportunities. Setting criteria and indicators for measuring progress provide for more transparency and can gain stakeholder support.

While the toxicological literature includes a fair amount of understanding regarding how the parameters related to climate change (temperature, $\mathrm{pH}$, salinity, dilution) affect contaminants, there is little application of these parameters in combination (as will often be the case with climate change). As a result, it will be necessary to develop approaches to remediation that can be adapted as new information is gathered in the treatment process.

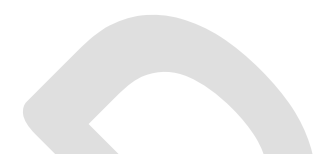

To be most effective, adaptation should be an iterative and flexible process that involves periodically re-evaluating the remediation system's vulnerability, monitoring the measures already taken, and incorporating newly identified options or information into the adaptation strategy. This involves consideration of short- and long-term availability of resources, such as energy and clean water, and ecosystem services as well as land uses of site or the surrounding area that may be critical aspects of the remediation system (EPA, 2015. As part of this iterative and flexible process site managers can use scenario planning that details future potential conditions in a manner that supports decision-making under conditions of uncertainty but does not predict future change that has an associated likelihood of occurrence (Glick, et al., 2014). 
Considering the role of remediation in greenhouse gases (GHGs) emissions is important. Energy- intensive remedies are often a significant source of GHGs. "At one remediation project in New Jersey, it was estimated that the difference between two proposed remedies could be as high as 2 percent of the annual greenhouse gas emissions

for the entire state.( Ellisat al 2009. Further, a meta-analysis indicated that the cleanup of $1 \mathrm{~kg}$ of contaminants in groundwater may result in up to 130 tonnes of $\mathrm{CO}_{2}$ emissions, with a geometric mean of 1.3 tonnes of $\mathrm{CO}_{2}$ emissions (Hou and Al-Tabbaa, 2014).

As part of the sustainable remediation assessment, these GHGs determinations can support decisions that reduce the manifestations of climate change on the site. Best management practices can be found in the ASTM Greener Cleanups and Consideration Sustainability in Remediation Projects Guidance.

Social vulnerability is an ability to cope with and adapt to any external stress placed on livelihoods and well-being (Adger et al., 1999). Adaptation strategies need to identify stakeholder concerns and address risk perception barriers. These strategies can include localized investigation to find answers to the questions about whom and what are vulnerable, to what are they vulnerable, how vulnerable are they, what the causes of their vulnerability are, and what responses can lessen their vulnerability (NOAA Community Social Vulnerability Indicators (CSVIs) (Coburn et al., 1994; .,). For example, the local community, municipal planners, and office of emergency management (OEM) representatives can inform site mangers on areas in and within the vicinity of the site that experience frequent nuisance flooding and are vulnerable to severe weather events. 
Strategies for resilient rehabilitation of contaminated sites should:

$>$ Involve the community throughout the cleanup and redevelopment process

B Build partnerships by collaborating with community advocacy groups, academia, and/or professional organizations for outreach activities,

Employ transdisciplinary processes that can help various stakeholders with different objectives and risk perceptions to reach consensus

$>$ Consider innovative measures such as social contracts that can link climate change and equity targets and measure progress in meeting community needs

Maximize opportunities to increase the well-being of vulnerable populations and creating value (direct and indirect) including public health benefits and jobs (part of the cleanup, long-term monitoring program, or through reuse of sites as parks or renewable energy deployment

D Coordinate policies across sectors of transport, land use, health, and energy $\underline{\text { Site Specific Protocols }}$

Aligned with these overarching principles are recommended site-specific protocols that begin with the EPA and ASTM guidance and recent Washington State guidance, Adaptation Strategies for Resilient Remedies (Washington State Department of Ecology [DOE], 2017). The WA DOE guidance is intended to: 1) help understand site-specific vulnerabilities of cleanup sites to climate change impacts, and 2) provide recommendations to increase resilience of remedies at each phase of cleanup. The guidance focuses on four climate change impacts: sealevel rise, flooding, landslides, and wildfires. The WA DOE guidance also includes examples of 
vulnerability analyses, a list of references, links to different technologies, adaptation plans, decision tools, case studies, and sustainable remediation resources.

Exhibit 3 depicts EPA's climate vulnerability and adaptation model which evaluates the sensitivity, exposure, and adaptive capacity of the site, contaminant, or remediation technique to climate change.

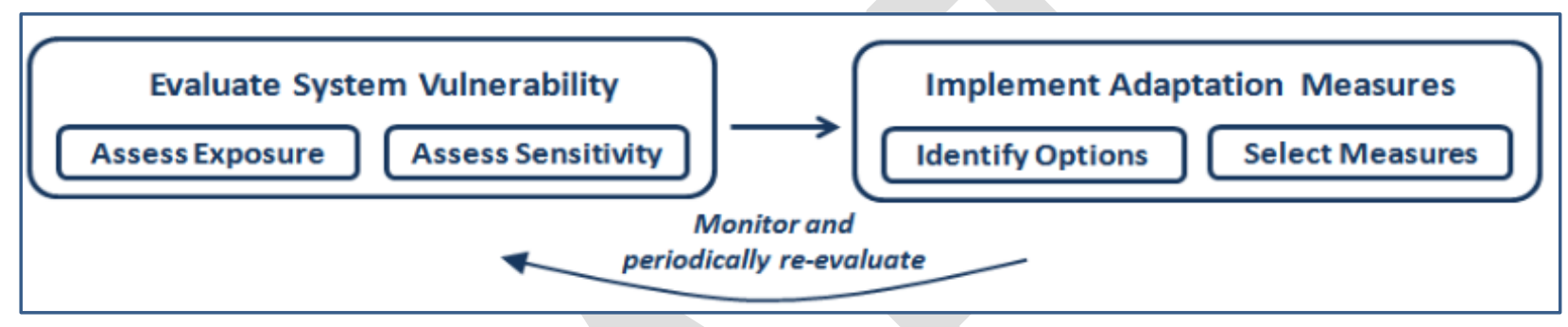

Exhibit 3 EPA climate vulnerability and adaptation model (EPA, 2013).

An evaluation of a system's vulnerability to climate change involves identifying climate change hazards of concern (such as treatment or containment systems) in light of potential climate/weather and considering factors that may exacerbate the system's exposure and sensitivity, such as a long operating period. 
For riverine and coastal sites, a vulnerability assessment may also encompass hydraulic and hydrological (H\&H modeling) or hydrodynamic modeling, respectively, to evaluate the role of precipitation projections, storm surge, surface water flow velocity, sea level rise, wave action, and/or wind action under existing and future storm events (e.g., 100-year storm event). The results of the modeling aid in remedial design, such as armor stone specifications for cap enhancement, and periodic climate change vulnerability monitoring, such as continuous monitoring of water levels, wave action, and flow velocity.

To support these vulnerability assessments, practitioners should use best available guidance (For an example see Exhibit 4 ASTM International Guidance for Climate

\section{Resiliency)}

and confer with local/regional experts and affected communities. Dynamic geospatial data are available from several sources, including federal, state, regional, or local sources such as watershed and forestry management authorities, non-profit groups, and academia

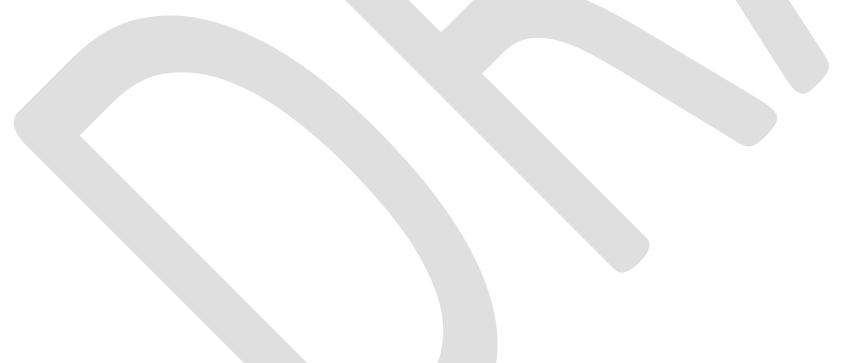

Exhibit 4 ASTM International Guidance for Climate Resiliency

\begin{tabular}{r|c|} 
The site vulne & \multicolumn{1}{c|}{ ASTM International Guidance } \\
Stakeholder engag & $\begin{array}{l}\text { Climate Resiliency Planning and Strategy (E3032-15e1) } \\
\text { Climate Resiliency in Water Resources (ASTM WK55606) }\end{array}$ \\
or public commen & $\begin{array}{l}\text { - addresses extreme weather, } \\
\text { climate change an }\end{array}$ \\
reflects general risks for certain regions of the country with \\
its matrix approach
\end{tabular}


The vulnerability assessment should identify the need for adaptation strategies and long-term vulnerability monitoring protocols as part of operation and maintenance (O\&M).

Adaptation strategies can also leverage existing regulatory tools such as the NCP long-term effectiveness and permanence (40 CFR 300.430(e)(9)(iii)(C)) and the Superfund Five-Year Reviews (Thun, 2017).

Five-Year Reviews should include the following elements (Thun, 2017):

- Evaluate remedy implementation/performance to determine protectiveness.

- Determine if the remedy functioning as intended. QUESTION C: Has any other information come to light that could call into questioned the protectiveness of the remedy?

- Address site changes or vulnerabilities that may be related to climate change impacts not apparent during remedy selection, remedy implementation or O\&M (e.g., sea level rise, changes in precipitation, increasing risk of floods, changes in temperature, increasing intensity of hurricanes and increasing wildfires, melting permafrost in northern regions, etc.).

- Determine if the assumptions, data, and cleanup levels still valid and, if there are issues, update O\&M or remedy decision.

\section{Adaptation Strategies Case Studies}

Adaptation strategies can be categorized as resistance, resilience, and response.

Resistance strategies maintain current conditions. They can include physical security, such as hardening covers, caps, and barriers to prevent flooding or erosion. Resistance strategies eventually will succumb to change or need to be increased at continuing cost. 
Resilience strategies allow sites to experience the change but still manage contaminant mitigation successfully. For example, to improve protectiveness and long-term effectiveness against more frequent severe storms, damaged portions of an intertidal cap at the Port Gamble Bay and Mill Site in Kitsap County, Washington were repaired and replaced with armor of rocks and other natural materials almost twice the original size. Washington DOE 2017 p 129)

Resilience strategies also include back-up power and remote and communication including automated data acquisition. An example developed by the Lawrence Berkeley Laboratory for the Department of Energy capitalizes on $21^{\text {st }}$ century technology through a new streamlined realtime data processing and analysis and early warning system for the Savannah River Superfund Site F-Area with a 50 percent cost saving (Exhibit 5, Wainwright, 2016).

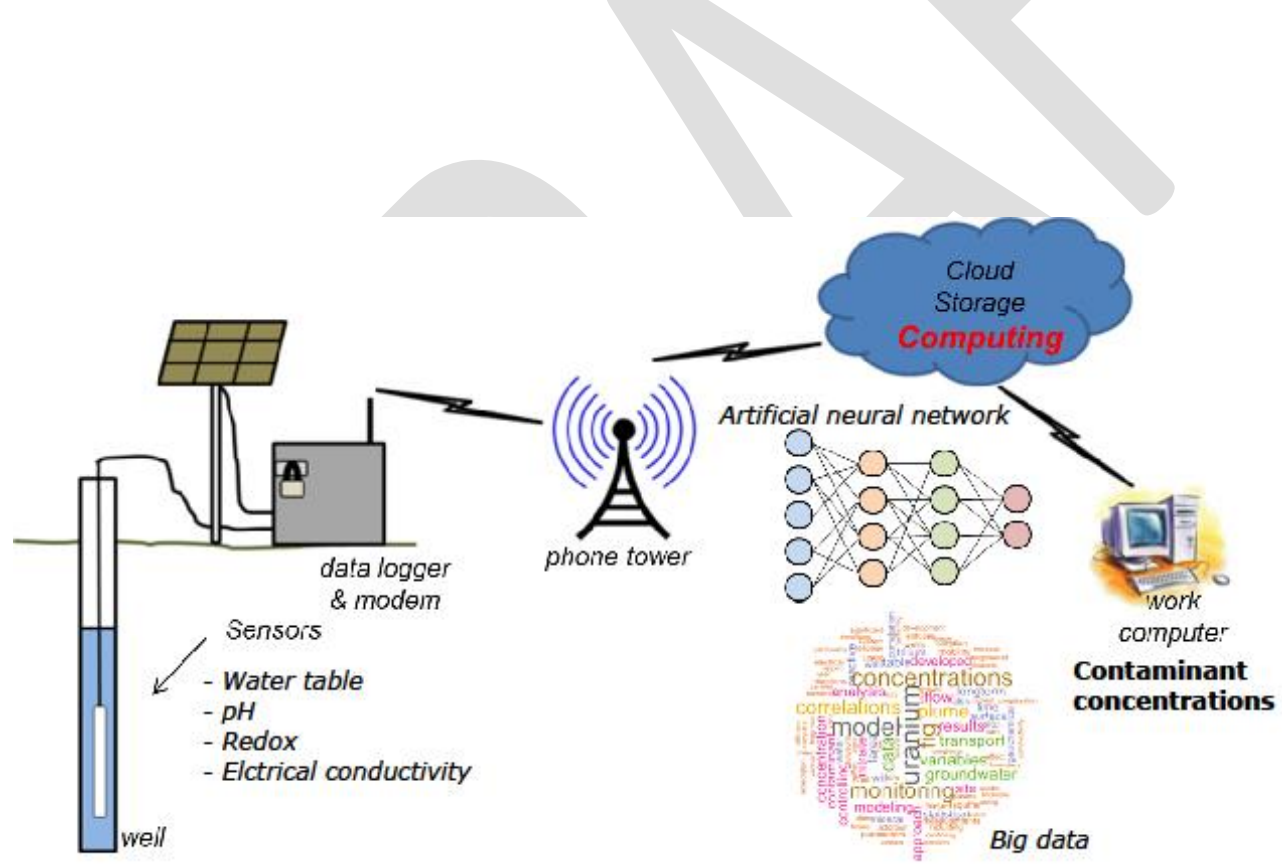

Exhibit 5 Water quality monitoring Savannah River Site F-Area: In situ sensors, wireless network, cloud computing 
Resilience strategies can also include the use of recycled water, including treated groundwater, to respond to drought conditions or salt water intrusion.

Another example of resilience comes from Huangshi in south central China, where intensive mining and smelting have caused significant air and water pollution and the contamination of nearby agricultural lands. Strip mining resulted in over 100 man-made bluffs, which are susceptible to landslides. One of the Rockefeller Foundation 100 resilient cities, Huangshi helped stabilize the land at these abandoned sites to prevent flooding and protect resources and human health. These efforts included controlling water pollution through sewage collection, water treatment, and increasing vegetation with ecological restoration projects.

Response strategies range from pre- and post-site inspection to removal of some or all of the contamination. For example, the New Jersey State Department of Environmental Protection developed response strategy guidance targeted to site owners and persons responsible for conducting and overseeing cleanup (i.e., "Licensed Site Remediation Professionals"). After storms, all sites should be re-evaluated to determine if any immediate environmental concerns needing action arose and whether site conditions changed requiring reassessment (New Jersey Department of Environmental Protection, 2016).

Responsible parties and regulators employed another effective response strategy at the Purity Oil Sales Superfund Site in Fresno, California. Over a period of 5 years, drought and agricultural pumping caused the groundwater table to drop more than 16 feet. The parties agreed to remove contamination from the newly-exposed vadose zone through soil vapor extraction (SVE). SVE expedited the cleanup and prevented further migration of contaminants to groundwater, removing contamination orders of magnitude greater than more traditional pumpand-treat systems (EPA, 2016). 
Another example of the impact of extreme weather and heavy precipitation, and the vital importance of adequate response strategies comes from Japan. Radionuclides from the Tokyo Electric Power Company Fukushima Daiichi nuclear power plant accident were released into the atmosphere and then deposited on land and sea surfaces. The government-commissioned decontamination work at the plant from 2011 to 2017, which generated approximately 20 million cubic meters of removed contaminated soil. Most of the soil was stored in approximately1,000 temporary storage facilities. Transportation of the soil to interim storage facilities started in 2015, and about 80 percent of the contaminated soil is still in the temporary storage sites. Heavy rainfall in September in 2015 caused torrential rains and flooding in the Kanto and Tohoku region in Japan, and the outflow of 448 of these temporary containers on agricultural land along two rivers. Emergency responders collected almost all the containers (five were left in the places inaccessible to the public and repaired). As follow-up, the Japan Ministry of the Environment developed guidelines, "Implementation of Appropriate Initial Response" for dealing with challenges associated with the storage of contaminated soil. For example, when disasters are predicted, storage areas need to be checked in advance, and parties need to implement an emergency response plan to minimize the damage of contaminant releases.

Post Florence, "In collaboration with state partners and once conditions allow" the EPA committed to deploy Superfund Reconnaissance Teams to conduct visual inspections of affected site, document site conditions, potential migration of contaminants, and restoration of utilities (if applicable), and complete the field survey check-list and photographs (EPA, 2018, P. 1[XX]).

In addition to the Washington and New Jersey initiatives highlighted above, Massachusetts and California have also established noteworthy programs as described below. Massachusetts enacted legislation (Green Communities Act and Global Warming Solutions Act) 
that provides rigorous clean energy goals designed to grow its clean energy economy, increase its energy independence, and reduce the pollution that contributes to climate change. The Massachusetts governor also issued an executive order establishing an Integrated Climate Change Strategy. The Massachusetts Department of Environmental Protection (MassDEP) promotes the use of "greener cleanup" principles and practices for the assessment and remediation of oil and hazardous material disposal sites through regulation and guidance, and is evaluating regulated sites and their vulnerability to climate change impacts through a statewide Geographic Information System (Potter, 2017).

California's Climate Adaptation Strategy can be leveraged to address climate resilience of contaminated lands, such as: 1) de-carbonized (40 percent GHG reduction from 1990 levels by 2030), decentralized energy (50 percent Renewables Portfolio Standard by 2030), and 2) protection of the most vulnerable communities through the Sustainable Communities and Climate Protection Act linking greenhouse gas reduction efforts to transportation and land planning requirements. California Climate Adaptation Strategy. Retrieved from http://climatechange.ca.gov/

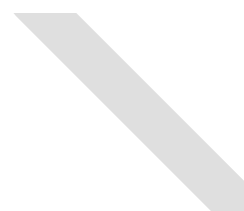

The State Water Resources Control Board Resolution \#2017-0012: Comprehensive Response to Climate Change provides support for drinking water systems and disadvantaged communities, and improve ecosystem resilience in response to the effects of climate change (California State Water Resources Control Board, 2017). Further, the Los Angeles Regional Water Quality Control Board Framework for Climate Change Adaptation and Mitigation (2015) 
looks at the impact of effects of climate change on contaminated sites and underground storage takes and how these effects can be taken into account in the Regional Water Board's actions. Finally, the California Department of Toxic Substances Control is developing climate change guidance specific to hazardous waste treatment, storage and disposal facilities, and the cleanup of contaminated sites.

\section{Climate Resilient Redevelopment: Drivers and Case Studies}

Over the last decade U.S. and European Union (EU) initiatives have sought to advance remediation by assessing the benefits of rehabilitated land in strengthening community, economic, and ecosystem resilience.

An EPA 5-year study of Brownfields found that residential property values increased from 5.1-12.8 percent after a nearby Brownfield was assessed or cleaned up (EPA SURF 2015). The study also determined that Brownfields cleanup can increase overall property values within a one-mile radius by $\$ 0.5$ to $\$ 1.5$ million. In 2016 , EPA also published guidance regarding Brownfield Revitalization in Climate-Vulnerable Areas including ordinance regulation and development incentives (EPA 2016).

Working for the City of San Francisco, (Hou et al. (2018) developed a method based on life cycle assessment of GHG emissions to compare Brownfields to Greenfield land development. The team examined three categories: 1) primary impact (associated with physical state of brownfield sites and greenfield sites), 2) secondary impact (associated with remediation activities at brownfield sites), and 3) tertiary impact (associated with post-remediation usage of the brownfield sites and avoided usage of greenfield land). Overall, the results show that the City's Brownfield land redevelopment could lead to a net GHG reduction of 51.9 million metric 
tons (Mt) $\mathrm{CO}_{2}$ eq. over a 70 -year period, or $0.74 \mathrm{Mt} \mathrm{CO}_{2} \mathrm{yr}^{-1}$, the equivalent of $14 \%$ of San Francisco's GHG emissions in 2010.

The RE-Powering America's Land Initiative, where EPA supports renewable energy development on potentially contaminated land, landfills, and mine sites, tracks the economic and environmental benefits associated with completed sites. Common benefits reported from developers/public agencies include revenues from land leases and taxes, electricity cost savings, job creation, and reduced greenhouse gas emissions.

A recently completed renewable energy project in the San Francisco Bay Area, the Marin Clean Energy (MCE) Solar One partnership, exemplifies the RE-Power America benefits. MCE Solar One repurposed 60 acres of a remediated Brownfields site leased by Chevron to MCE Solar One for \$1 per year. At 10.5 megawatts, MCE Solar One will eliminate 3,234 metric tons of carbon dioxide in one year, equivalent to taking more than 680 cars off of the road annually. MCE Solar One provided community benefit by partnering with RichmondBUILD, a public-private partnership that focuses on training for skilled construction, hazardous waste removal, and renewable energy jobs. All RichmondBUILD participants come from low-income households. In addition, almost \$2 million dollars was spent on project materials purchased or rented locally. The project also includes an innovative procurement approach called “community choice energy," in which a public agency offers citizens and businesses an alternative to the utility for purchasing their electricity. As a result of the MCE Solar One project, homes and businesses now benefit from a more renewable electricity option that costs two to five percent less than the traditional Bay Area utility rates. 
https://www.mcecleanenergy.org/news/press-releases/mce-solar-one-thinking-globally-building-

locally

\section{EU and UK Drivers and Case Studies}

There is presently a trend across Europe for densification as a planning approach for sustainable development to foster efficient use of resources, efficient transport systems, and a vibrant urban life (e.g., Haaland \& van den Bosch, 2015). Development often takes place on areas that are often viewed as underutilized land (such as green space, marginal land) or through redevelopment on previous industrial estates (derelict, brownfield sites). However, this approach has also been challenged for its threat to urban green spaces (Haaland and van den Bosch, 2015) since together with urban brownfields they potentially have an important role for offering climate change adaptation solutions.

This is strongly related to a much wider European debate about "Nature Based Solutions" (NBS), their importance in urban areas and how they might be managed and, if necessary, regenerated. The concept of NBS was introduced towards the end of the 2000s by the World Bank (MacKinnon et al., 2008) and International Union for Conservation of Nature (IUCN, 2009) to highlight the importance of biodiversity conservation for climate change mitigation and adaptation. NBS were proposed by IUCN for inclusion in the climate change negotiations in Paris "as a way to mitigate and adapt to climate change, secure water, food and energy supplies, reduce poverty and drive economic growth." (IUCN, 2014). TheICUN proposed principles for NBS included cost efficiency, harnessing both public and private funding, ease of 
communication, and replicability of solutions (van Ham, 2014). Thus, NBS puts an explicit emphasis on linking biodiversity conservation with goals for sustainable and climate resilient development (Eggermont et al. 2015), and represent innovative, implementable 'solutions'.

The Holistic Management of Brownfield Regeneration (HOMBRE) was a major EU project completed in 2014 (www.zerobrownfields.eu), examining the enhanced transition of brownfields through to becoming once more a functional part of the land cycle. One of its areas of interest was in "soft," i.e., non-built reuse of brownfields, the services this might provide, and how those might be appreciated and valued. One of the outputs of this work is a simple Excel design aid to help developers and others involved in Brownfields map the range of opportunities, the resulting value, and the initial default design considerations by identifying specific opportunities for synergies between different "services" such as risk management, water improvement, and renewable energy

Case Study: Brownfields Redevelopment as Wetlands Park and Community Management

Port Sunlight Riverside Park. Port Sunlight River Park (PSRP) is a 28-hectare park near Birkenhead in Wirral, Merseyside, U.K., which opened in 2014. It is located on a former landfill capped and covered by the waste management company (Biffa Waste Management) and leachate and gas management systems were put in place. The site was passed over to the Land Trust on a 99 year lease and, after planning and design, was created as a riverside park in 2013. The waste management company remains responsible for ongoing management and monitoring of the capping, landfill gas, and leachate treatment. 
The Land Trust secured a $£ 3.4$ million investment for a transformation project encompassing park creation, site of special protection and ongoing management, and established a partnership with the charity, Autism Together, which manages the park.

A retrospective qualitative sustainability assessment was performed by the University of Brighton in 2016. The aim of the sustainability assessment was to understand the economic, environmental, and social benefits/disbenefits of transforming the former landfill into a public open space, managed long term. (Li et al., 2017), using SURF-UK qualitative sustainability assessment guidance (www.claire.co.uk/surfuk) enhanced with the HOMBRE idea of conceptual site models of sustainability (Bardos et al., 2016). Climate change-related considerations were a significant part of the sustainability assessment, including emissions of carbon to atmosphere versus sequestration; and economic factors such as the project's future resilience. Unsurprisingly, the re-use of the capped landfill as a public park showed substantive sustainability improvement.

Anticipate Adsorb Reshape (“A2R”), a United Nations Climate Resilience Initiative to support sustainable, resilient cleanup and reuse of hazardous sites. A2R focuses on the capacity to reshape development pathways by: 1) transforming economies to reduce risks and root causes of vulnerabilities, and 2) supporting the sound management of physical infrastructure and ecosystems to foster climate resilience.

Complementing A2R is the World Bank vision of contaminated sites as "engines for economic development, sources of sustainable energy, food security \& efficiency—all while assuring public health and environmental protection" (World Bank, 2009 p1 ).

\section{Conclusions}


SURF's recommendations can guide owners and project managers in developing a site resiliency strategy. By following a systematic, holistic approach with the site end use in mind, and by meeting priority social and economic needs, climate-resilient sustainable remediation and redevelopment can reduce public health risks and create long-term value for communities. SURF plans to partner with the private and public sector to support pilot studies and conduct national and international capacity-building.

Acknowledgements to the entire SURF Climate Change and Resilience technical initiative team, Arianna Libera of University of Southern California, and all the presenters and participants of SURF Conferences 31-35. 


\section{Authors}

Barbara Maco, MBA, Sustainable Management has worked over 25 years in both the public and private sector to support clients with projects advancing sustainable rehabilitation of impaired lands. At the U.S. Environmental Protection Agency, Barbara served as senior superfund project manager, international disaster prevention liaison, air quality specialist and environmental justice coordinator. She's now sustainability director for Wactor \& Wick LLP. Barbara holds a BA in Ecological Systems from the University of California Los Angeles and an MBA in Sustainable Management from the Presidio School of Management, SF CA.

Paul Bardos, Ph.D. Dr. Bardos is an Adjunct Professor at the University of Brighton working in contaminated land and waste management, renewable energy, brownfields rehabilitation, and sustainability assessment. He is also the managing director of r3 Environmental Technology Ltd (www.r3environmental.com). r3 offers a range of research, management and consultancy services in brownfields and circular economy technical areas. He is a Visiting Professor at the University of Reading, co-chair of SuRF UK, and international expert on GSR for the Foreign Economic Cooperation Office (FECO) of the Ministry of Environmental Protection (MEP)

Frederic Coulon, Professor, Ph.D., holds a chair in Environmental Chemistry \& Microbiology at Cranfield University (UK) and is recognised for his internationally leading contribution on water, soil and wastewater treatment, resource recovery and environment, and public communication of environmental science and engineering. and for advancing a nexus approach to enable integrated and sustainable management of water, soil and waste systems. He has published numerous articles in leading environmental engineering and science journals; book chapters and articles for the popular press with substantive contributions to oil remediation, process emission and control at industrial sites and environmental risk management.

\section{Emerald Erickson-Mulanax, L.G., R.G., Associate Geologist}

Farallon Consulting | MS Geology BS Earth and Space Sciences

Emerald has more than 9 years of environmental consulting experience, and conducts services for clients in Washington and Oregon that include soil, air, and groundwater monitoring and site assessments. She also has experience in UST closure, remedial construction observation, cleanup compliance monitoring, EPA 104(e) response preparation, Superfund cleanup allocation processes and environmental response preparation, and litigation support. Emerald is Farallon's Green Initiative lead, and is an active member of the Sustainable Remediation Forum.

Lara J. Hansen, Ph.D., is the Chief Scientist and Executive Director of EcoAdapt an adaptation science research organization on Bainbridge Island, Washington. She is co-- author of two books on climate change adaptation (Buying Time: A User's Manual for Building Resistance and Resilience to Climate Change in Natural Systems and Climate Savvy: Adapting Conservation and Resource Management to a Changing World), and co-creator of the Climate Adaptation Knowledge Exchange (CAKEx.org). Dr. Hansen earned her Ph.D. at the University of 
California, Davis in Ecology (with a focus in Ecotoxicology) and her B.A. in Biology at the University of California, Santa Cruz.

Melissa Harclerode, PhD, BCES, ENV SP is an environmental sustainability scientist with CDM Smith, in the Edison, NJ office. Specifically, she specializes in the development and application of integrated assessment approaches to comprehensively define sustainability and resiliency objectives and evaluate environmental, social, and economic impacts of environmental, water resources, transportation, and restoration projects.

Deyi Hou, PhD, PE, LEED AP is an Associate Professor and Assistant Dean at the School of Environment in Tsinghua University, Beijing, China. His research interest includes: contaminant fate and transport in soil and groundwater, contaminated land remediation, climate change and sustainability implications of brownfield redevelopment, public participation and environmental behavior. He has published over 30 journal papers in the field of green and sustainable remediation. Dr. Hou received his B.E. in Environmental Engineering from Tsinghua University, his M.S. in Civil and Environmental Engineering from Stanford University, and his Ph.D. in Engineering from the University of Cambridge.

Eric Mielbrecht, M.S., is a Directing Scientist at EcoAdapt, an adaptation science research organization on Bainbridge Island, Washington. He specializes in assessing anthropogenic stresses and the risks they pose in natural and built environments, and is particularly interested in working with stakeholders to bridge gaps between research, decision-making processes and action. Mr. Mielbrecht received his B.A. in Biology and M.S. in Marine Science/Environmental Toxicology from the University of California, Santa Cruz.

Haruko M. Wainwright, Ph.D., is a research scientist at Lawrence Berkeley National Laboratory. Her research has been focused on numerical modeling, parameter estimation and uncertainty quantification in soil and groundwater remediation, watershed science and other environmental topics. Dr. Wainwright has received his B.S. in Engineering Physics from Kyoto University (Japan), M.S. in Nuclear Engineering, M.A. in statistics, and Ph.D. in Nuclear Engineering (2010) at University of California, Berkeley.

Tetsuo Yasutaka, Ph.D. ,Senior Researcher of Research Institute for Geo-Resources and Environment, National Institute of Advanced Industrial Science and Technology. His research interests include the risk assessment of the contaminated soil containing heavy metal and radioCesium. Dr. Yasutaka received his B.S. and M.S. in Agriculture from Kyoto University and his Ph.D. in Environmental Science from Yokohama National University

Mr. William D. Wick is a founding partner of Wactor \& Wick LLP. His practice is devoted to environmental counseling and litigation, with a focus on assisting clients with all issues relating to contaminated land. Bill has more than 38 years of experience in prosecuting, defending, and serving as an expert witness in environmental cases. Bill served as an enforcement attorney with the EPA for 13 years. During his last six years at EPA, he was Chief of the Hazardous Waste Branch of the Region IX Office of Regional Counsel, developing enforcement policy and supervising the 30 attorneys enforcing CERCLA, RCRA and TSCA. He has authored chapters 
on liability at hazardous sites in two legal treatises. Bill received a B.A. from Northwestern University and law degree from Georgetown University Law Center.

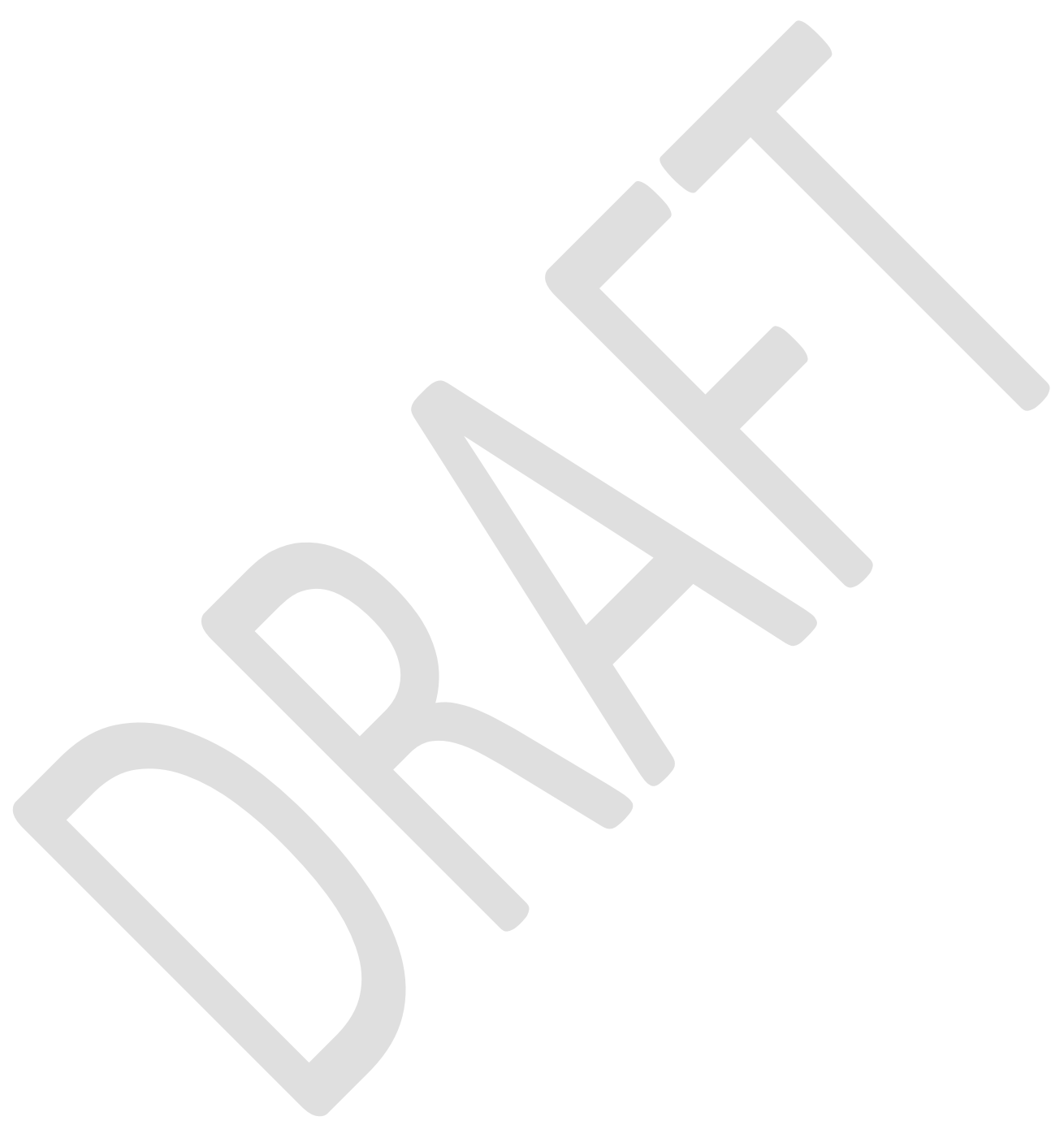




\section{References}

Adger, W. N., \& Kelly, M. (1999). Social vulnerability to climate change and the architecture of entitlements. Mitigation and Adaptation Strategies for Global Change, 4, 253-266.

Andersson-Sköld, Y., Bardos, P., Chalot, M, Bert, V., Crutu, G., Phanthavongsa, P., Delplanque, M., Track, T., Cundy, A. B. (2014). Developing and validating a practical decision support tool (DST) for biomass selection on marginal land. Journal of Environmental Management, 145, 113121.

ASTM International, Inc. (2017). Standard Guide for climate resiliency planning and strategy (E3032-15e1). Conshohocken, PA: Author.

Bardos, P., Bakker, L., Slenders, H. and Nathanail, P. (2011). Sustainable Remediation. (pp 889948) In: F.A. Swartjes (Ed.), Dealing contaminated sites - From theory towards practical application, Dordrecht, Netherlands: Springer Netherlands. ISBN: 978-90-481-9756-9.

Bardos, P., Thomas, H. J., Smith, J. W. N., Harries, N. D., Evans, F., Boyle, R., Howard, T., Lewis, R., Thomas, A. O., \& Haslam, A. (2018). The development and use of sustainability criteria in surf-uk's sustainable remediation framework. Sustainability, 10(6), 1781-1803.

Bardos, P., Jones, S., Stephenson, I., Menger, P., Beumer, V., Neonato, F., Maring, L., Ferber, U., Track, T. and Wendler, K. (2016). Optimising value from the soft re-use of brownfield sites. Science of the Total Environment, 563-564, 769-782. DOI 10.1016/j.scitotenv.2015.12.002. http://dx.doi.org/10.1016/j.scitotenv.2015.12.002.

California Climate Adaptation Strategy. Retrieved from http://climatechange.ca.gov/

Coburn, A. W., Spence, R. J. S., \& Pomonis, A. (UNDP Disaster Management Training Programme ) (1994). Vulnerability and risk assessment, Second Edition. Cambridge, U.K.: Cambridge Architectural Research Limited.

Bartsch, Charlie (2015 February 24) A Big Picture Look at the Benefits of Greener Cleanups U.S. EPA SURF 28: Moving Sustainable Remediation Forward, Arlington, Virginia

Dearen, J., Biesecker, M., \& Kastanis, A.. (2017, December 22). AP finds climate change risk for 327 toxic Superfund sites. Associated Press. Retrieved from: https://apnews.com/31765cc6d10244588805ee738edcb36b/AP-finds-climate-change-risk-for327-toxic-Superfund-sites. 
Ellis, D. E., \& Hadley, P. W. (2009). Sustainable remediation white paper - Integrating sustainable principles, practices, and metrics into remediation projects. Remediation Journal, 19(3), 5-114.

Eggermont H, Balian E, Azevedo JMN, Beumer V, Brodin T, Claudet J, Fady B, Grube M, Keune H, Lamarque P, Reuter K, Smith M, van Ham C, Weisser WW, Le Roux X (2015) Nature-based solutions: new influence for environmental management and research in Europe. Gaia 24(4):243-248

Famiglietti, J. S. (2014). The global groundwater crisis. Nature Climate Change, 4(11), 945.

Fausset, R. (2018, September 18). At water's edge, A hostage to nature and poverty. New York Times.

Glick, P., B.A. Stein, and N.A. Edelson, editors, 2011. Scanning the Conservation Horizon: A Guide to Climate Change Vulnerability Assessment. National Wildlife Federation, Washington, D.C.

Haaland, C., Konijnendijk van den Bosch C. (2015) Challenges and strategies for urban greenspace planning in cities undergoing densification: a review. Urban For Urban Green 14(4):760771.

Hansen, L. J., Biringer, J., \& Hoffman, J. R. (2003). Buying time: A user's manual for building resistance and resilience to climate change in natural systems. Washington, DC: World Wildlife Federation.

Haaland, C., \& van den Bosch, C. K. (2015). Challenges and strategies for urban green-space planning in cities undergoing densification: A review. Urban for Urban Green, 14(4):760-771.

Hansen, L. J., \& Hoffman, J. R. (2011). Climate savvy: Adapting conservation and resource management to a changing world. Washington, DC: Island Press.

Harclerode, M., Ridsdale, D. R., Darmendrail, D., Bardos, P., Alexandrescu, F., Nathanail, P., Pizzol, L., \& Rizzo, E. (2015). Integrating the social dimension in remediation decision-making: State of the practice and way forward, Remediation, 26(1), 11-42.

Hibbard, D., Dokken, J., Stewart, B. C., \& Maycock, T. K. (eds.)].2017 U.S. Global Change Research Program, Washington, DC, pp.12-34, doi: 10.7930/J0DJ5CTG.

https://www.epa.gov/land-revitalization/revitalization-tools-communities extracted January 20 2017. 
Hou D, Al-Tabbaa A. Sustainability: A new imperative in contaminated land remediation. Environmental Science and Policy 2014; 39: 25-34.

Hou D, Li F. Complexities Surrounding China's Soil Action Plan. Land Degradation \& Development 2017; 28: 2315-2320.

Hou D, Li G, Nathanail P. An emerging market for groundwater remediation in China: Policies, statistics, and future outlook. Frontiers of Environmental Science \& Engineering 2018; 12.

Hou D, Song Y, Hou M, O'Connor D, Harclerode, M. 2018. Climate change mitigation potential of contaminated land redevelopment: A city-level assessment method, Journal of Cleaner Production Volume 171, , Pages 1396-1406.

http://www.zerobrownfields.eu/Displaynews.aspx?ID=568 and http://bfn.deltares.nl

International Union for the Conservation of Nature (IUCN). (2009) No time to lose: make full use of nature-based solutions in the post-2012 climate change regime. Position paper on the fifteenth session of the conference of the parties to the United Nations Framework Convention on Climate Change (COP 15). Retrieved from:

https://www.iucn.org/sites/dev/files/import/downloads/iucn_position_paper_unfccc_cop_15.pdf.

International Union for the Conservation of Nature (IUCN). (2014). Nature-based solutions. Retrieved from: http://www.iucn.org/about/union/secretariat/offices/europe

Japan Ministry of the Environment. (2015). The countermeasure for accident that outflow of the radio Cs contaminated soil by the Kanto-Tohoku Heavy Rainfall in September 2015. Retrievd from: https://www.env.go.jp/jishin/rmp/conf/16/mat06.pdf.

Liu K, Huisingh D, Zhu J, Ma Y, O'Connor D, Hou D. Farmers' perceptions and adaptation behaviours concerning land degradation: A theoretical framework and a case- study in the Qinghai-Tibetan Plateau of China. Land Degradation \& Development 2018; 29: 2460-2471.

Xiaonuo Li et al., Sustainability of Brownfield Regeneration for Soft Reuse: A Case Study of Port Sunlight River Park (PSRP) Summary Report (2017). 
Libera, A.; de Barros, F.P.J.; Faybishenko, B.; Eddy-dilek, C.; Denham, Lipnikov, K.; M.; Moulton, D.; Maco, B., Wainwright, H. M. Climatic controls on residual contaminants under sustainable remediation. Submitt. to Environ. Sci. Technol. 2017.

Massachusetts Department of Environmental Protection. (2014, October). Greener cleanups guidance. Boston, MA: Author.

Massachusetts Executive Office of Energy and Environmental Affairs. ([DATE]) Climate change adaptation Retrieved from: http://www.mass.gov/eea/waste-mgnt-recycling/airquality/climate-change-adaptation/.

MacKinnon, K., Sobrevila, C., Hickey, V. et al. (2008). Biodiversity, climate change and adaptation: Nature-based solutions from the Word Bank portfolio. Washington, DC: World Bank.

Millero, F. J., Woosley, R., DiTrolio, B, \& Waters, J. (2009). Effect of ocean acidification on the speciation of metals in seawater. Oceanography, 22(4), 72-85.

Nadal, M., Marques, M., Mari, M., \& Domingo, J. (2015). Climate change and environmental concentrations of POPs: A review. Environmental Research, 143A, 177-185.

National Wildlife Federation. (2014). Climate-smart conservation: Putting adaptation principles into practice. Washington, DC: Author.

New Jersey Department of Environmental Protection. ([DATE]). Vapor mitigation systems and power outages fact sheet. Retrieved from: https://emea01.safelinks.protection.outlook.com/?url=www.nj.gov\%2Fdep\%2Fsrp\%2Fgui dance\%2Fvaporintrusion\%2Fvapor_mit_sys_and_power_outages.pdf\&data=01\%7C01\%7Cleroy bealer\%40shell.com\%7C2af7b2a27dc2473609bf08d5837a0ff3\%7Cdb1e96a8a3da442a930b235 cac24cd5c\%7C0\&sdata=qOaCZnGb75vmQmMgp6RClVIhkGFQ\%2FeoLmvog93YDC3s\%3D \&reserved $=0$.

New Jersey Department of Environmental Protection (NJDEP). (2016, June). Technical guidance: Planning for and response to catastrophic events at contaminated sites. Trenton, NJ: Author. 
Noyes, P., McElwee, M., Miller, H., Clark, B., Van Tiem, L., Walcott, K., Erwin, K., \& Levin, E. (2009). The toxicology of climate change: Environmental contaminants in a warming world. Environment International, 35(6), 971-986.

O'Connell, D., \& Hou, D. (2015). Resilience: A new consideration for environmental remediation in an era of climate change. Remediation Journal, 26(1), 57-67.

Potter, T. M. (2017). Massachusetts Climate Change Mitigation and Adaptation for Site Assessment \& Remediation, Association for Environmental Health and Sciences Conference, October 18, Amherst, MA.

Holland, K. S., Lewis, R. E., Tipton, K., Karnis, S., Dona, C., Petrovskis, E., Bull, L. P., Taege, D., \& Hook, C. (2011). Framework for integrating sustainability into remediation projects.

Remediation, 21, 7-38.

New Jersey Department of Environmental Protection (NJDEP). (2016, June). Technical guidance: Planning for and response to catastrophic events at contaminated sites. Trenton, NJ: Author.

Pierre-Louis, K, Popovich N and Tabuchi H. (2018, Sept. 24) Florence's Floodwaters Breach Coal Ash Pond And Imperil Other Toxic Sites New York, NY: New York Times.

Plumer, B. (2017, November 9). Trump ignores climate change. That's very bad for disaster planners. New York, NY: New York Times.

Targ, N. (2017). Regulatory and legal perspectives. SURF 34 Meeting, Pasadena, CA, April 56, 2017.

Thun, R.(2017). Remedy resiliency to extreme weather events. SURF 34 Meeting, Pasadena, CA, April 5-6, 2017.

U.S. Global Change Research Program (2017). Volume II of NCA4--Climate Change Impacts, Risks, and Adaptation in the United States- Draft report. Washington, DC: Author.

United Nations. (2017). Climate resilience initiative A2R anticipate adsorb reshape. Retrieved from: http://www.a2rinitiative.org/.

U.S. Environmental Protection Agency (EPA). (2016). Adaptation of Superfund remediation to climate change. Presentation at SURF 31 Meeting, Arlington, VA, March 2, 2016. 
U.S. Environmental Protection Agency (EPA). (2016). Brownfield revitalization in climatevulnerable areas. Retrieved from: https://www.epa.gov/sites/production/files/2016-

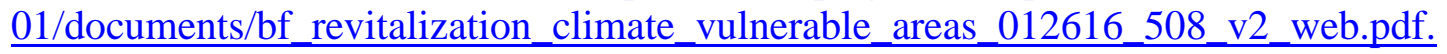

U.S. Environmental Protection Agency (EPA). Climate change impacts on the Superfund program, Climate change adaptation within the Superfund program and Climate change impacts potentially affecting remediation vulnerability. https://www.epa.gov/superfund/superfundclimate-change-adaptation extracted 11 July 2018.

https://www.epa.gov/superfund/superfund-climate-change-adaptation-information-sources

U.S. Environmental Protection Agency (EPA). (2017). Climate smart brownfields manual. Retrieved from: https://www.epa.gov/sites/production/files/2017-

01/documents/final_climate_smart_brownfields_manual_online_version.pdf.

U.S. Environmental Protection Agency (EPA). (2013). Climate change adaptation technical fact sheet: Groundwater remediation systems, EPA 542-F-13-004. Washington, DC: EPA, Office of Superfund Remediation and Technology Innovation.

U.S. Environmental Protection Agency (EPA). (2014). Climate change adaptation technical fact sheet: Landfills and containment as an element of site remediation, EPA 542-F-14-001. Washington, DC: Office of Superfund Remediation and Technology Innovation.

U.S. Environmental Protection Agency (EPA). (2015). Climate change adaptation technical fact sheet: Contaminated sediment remedies, EPA 542-F-15-009. Washington, DC: Office of Superfund Remediation and Technology Innovation.

U.S. Environmental Protection Agency (EPA). (2018). RE-Powering America's Land Initiative: Benefits matrix. Retrieved from: https://www.epa.gov/sites/production/files/2018-

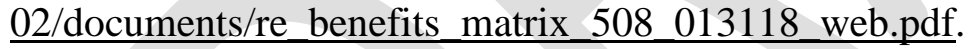

U.S. Environmental Protection Agency (EPA). (2018 september 18). Hurricane Florence response. Retrieved from: https://response.epa.gov/site/site_profile.aspx?site_id=13923

U.S. Global Change Research Program. (2017). Volume II of the National Climate Assessment. Washington, DC: Author.

U.S. Global Change Research Program. (2017). Volume 1 of the National Climate Assessment. Washington, DC: Author.

U.S. National Oceanic and Atmospheric Administration (NOAA (2016) State of the climate: Global analysis for July 2016. August. http://www.ncdc.noaa. gov/sotc/global/201607

Van Ham, C. (2014). Pioneering nature-based solutions for cities. Retrieved from : http://urbionetwork.org/data/documents/2014-10-11_11-OR3-4-02_van_Ham.pdf 
Wainwright. H. (2016). New paradigm of groundwater monitoring for sustainable remediation. Arlington, VA, October 19-20, 2016.

Washington State Department of Ecology (Washington DOE), Toxics Cleanup Program. (2017, November). Adaptation strategies for resilient cleanup remedies: A guide for cleanup project managers to increase the resilience of toxic cleanup sites to the impacts from climate change. Publication No. 17-09-052. Retrieved from:

https://fortress.wa.gov/ecy/publications/SummaryPages/1709052.html.

World Bank Group (2014). Financing Mechanisms for Addressing Remediation of Site Contamination. Washington, DC: Author.

World Bank. (2009). Systems of cities: Harnessing urbanization for growth and poverty alleviation. Washington, DC: Author.

Wuebbles, D. J., Fahey, D. W., Hibbard, K. A., DeAngelo, B., Doherty, S., Hayhoe, K., Horton, R., Kossin, J. P., Taylor, P. C., Waple, A. M., \& Weaver, C. P. (2017). Executive summary, Climate science special report: Fourth national climate assessment, Volume I. U.S. Global Change Research Program: Washington, DC. 